\title{
Flexible Vertex Engineers the Controlled Assembly of Distorted Supramolecular Tetrahedral and Octahedral Cages
}

\author{
Shu-Jin Bao, ${ }^{1,2}$ Ze-Ming Xu, ${ }^{1}$ Tian-Chen Yu, ${ }^{3}$ Ying-Lin Song, ${ }^{3}$ Heng Wang, ${ }^{4}$ Zheng Niu (D), \\ Xiaopeng Li, ${ }^{4}$ Brendan F. Abrahams, ${ }^{5}$ Pierre Braunstein, ${ }^{6}$ and Jian-Ping Lang $\mathbb{D}^{1,2}$ \\ ${ }^{1}$ College of Chemistry, Chemical Engineering and Materials Science, Soochow University, Suzhou 215123, China \\ ${ }^{2}$ State Key Laboratory of Organometallic Chemistry, Shanghai Institute of Organic Chemistry, Chinese Academy of Sciences, \\ Shanghai 200032, China \\ ${ }^{3}$ School of Physical Science and Technology, Soochow University, Suzhou 215006, China \\ ${ }^{4}$ College of Chemistry and Environmental Engineering, Shenzhen University, Shenzhen 518071, China \\ ${ }^{5}$ School of Chemistry, University of Melbourne, Victoria 3010, Australia \\ ${ }^{6}$ Université de Strasbourg-CNRS, Institut de Chimie (UMR 7177 CNRS), 4 Rue Blaise Pascal CS 90032, 67081 Strasbourg, France \\ Correspondence should be addressed to Zheng Niu; zhengniu@suda.edu.cn and Jian-Ping Lang; jplang@suda.edu.cn
}

Received 6 December 2021; Accepted 31 December 2021; Published 24 February 2022

\begin{abstract}
Copyright (c) 2022 Shu-Jin Bao et al. Exclusive Licensee Science and Technology Review Publishing House. Distributed under a Creative Commons Attribution License (CC BY 4.0).

Designing and building unique cage assemblies attract increasing interest from supramolecular chemists but remain synthetically challenging. Herein, we propose the use of a flexible vertex with adjustable angles to selectively form highly distorted tetrahedral and octahedral cages, for the first time, in which the flexible vertex forms from the synergistic effect of coordination and covalent interactions. The inherent interligand angle of the vertex can be modulated by guest anions present, which allows for the finetuning of different cage geometries. Furthermore, the reversible structural transformation between tetrahedral and octahedral cages was achieved by anion exchange monitored by mass spectrometric technique, the smaller anions favoring tetrahedral cages, while the larger anions supporting octahedral cages. Additionally, the $\mathrm{KBr}$-based cage thin films exhibited prominent enhancement of their third-order NLO responses in two or three orders of magnitude compared to those obtained for their corresponding solutions. This work not only provides a new methodology to build irregular polyhedral structures in a controlled and tunable way but also provides access to new kinds of promising functional optical materials.
\end{abstract}

\section{Introduction}

Over the past decades, designing and synthesizing unique supramolecular cages featuring intriguing polyhedral geometries and confined cavities have sparked great interest in supramolecular community [1-6]. In addition to their aesthetically pleasing structures, their unique physical and chemical properties resulting from specific shapes and functionalities endow them wide applications across various fields, ranging from biomedicine [7-9], catalysis [10-14], guest encapsulation [15-17], separation $[18,19]$ to luminescent materials [20-22]. Recent progress allows the structures of supramolecular cages to be readily designed and synthesized using highly directional coordination bonds linking metal ions with specific coordination geometries with organic linkers of different symmetries, lengths, and steric bulk [1-6, 23-26]. If the directionality of coordination bonds has critically contributed to spectacular developments in the field, access to only a limited number of interligand angles significantly hinders the development of higher structural diversity and complexity $[27,28]$. Typically, the most encountered interligand angles are centered around $60^{\circ}, 90^{\circ}$, and $109^{\circ}$ and cannot be easily modified because they are dictated by the nature of the metal center [28]. These angles favor the formation of regular cages with tetrahedral, octahedral, cubic, $\mathrm{M}_{\mathrm{n}} \mathrm{L}_{2 \mathrm{n}}$-type polyhedral, and adamantanoidal structures (Figure 1(a)) [1, 29, 30]. Consequently, being able to adjust the interligand angles at a vertex would represent a highly desirable and major step forward to efficiently expand the existing libraries of molecular cages. 


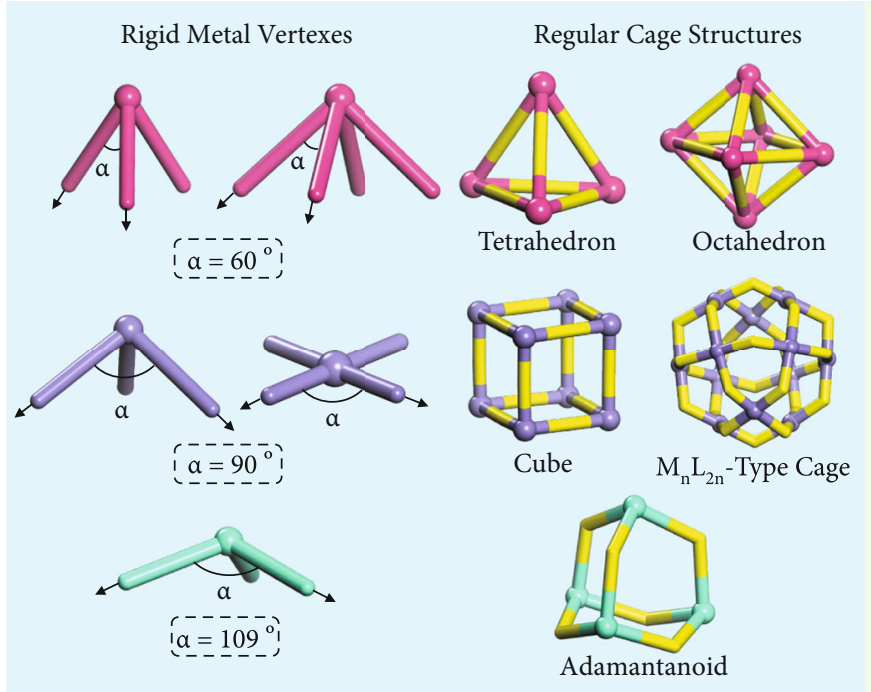

(a)

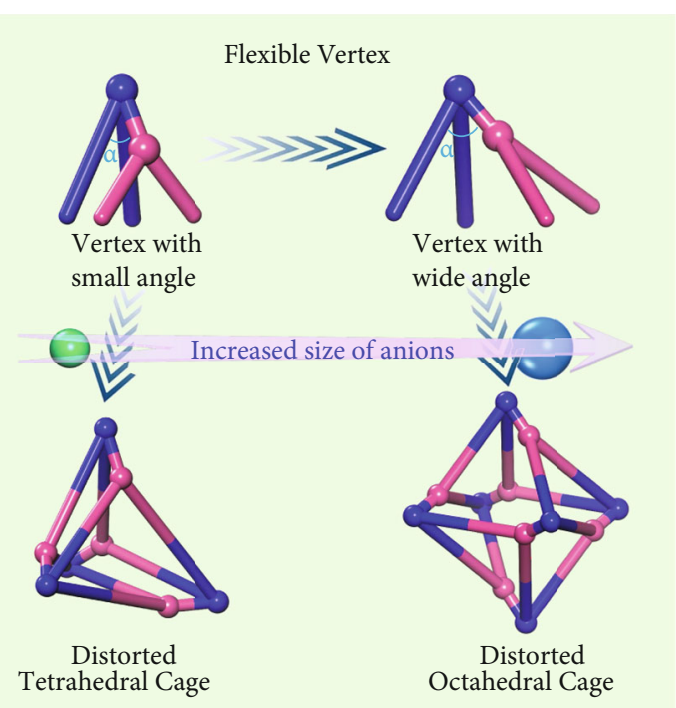

(b)

FIGURE 1: Types of metal coordination building blocks used for constructing supramolecular cage structures. (a) Previous work showing the current use of rigid metal vertexes with predetermined interligand angles $\left(60^{\circ}, 90^{\circ}\right.$, and $\left.109^{\circ}\right)$, leading to regular cage structures, mainly tetrahedral, octahedral, cubic, $\mathrm{M}_{\mathrm{n}} \mathrm{L}_{2 \mathrm{n}}$-type polyhedral, and adamantanoidal cages. (b) New design approach proposed in this work. Taking advantage of a type of flexible coordination vertex capable of adapting angular changes in response to the changes of the size of guest anions, the controlled construction of distorted supramolecular tetrahedral and octahedral cages can be achieved.

However, the coordination interaction-based vertices used for the construction of supramolecular cage architectures are limited to single/double metal nodes [1,31] and metal cluster nodes (carboxylate-containing and polyoxometalate clusters) [32-35], which are quasirigid elementary bricks that significantly restrict angular changes on vertexes. Therefore, the introduction of additional interactions, such as covalent interactions, would provide vertexes with higher flexibility and distorted characteristic and thus access to unconventional supramolecular cages [36]. In particular, if the variable angles at a flexible vertex could be tuned by an external stimulus, such as a guest molecule, the controllable construction of diverse supramolecular cage architectures would be more readily accessible [5, 37-40].

We herein report a new strategy based on a type of flexible vertex with adjustable angles to selectively construct a series of severely distorted tetrahedral and octahedral cages. The synergistic effect of both coordination and covalent interactions gives the vertex flexible and low-symmetry merits. Consistent with the possibility of the associated anion to act as a template and guide the assembly of supramolecular structures [41-45], we have now observed that the size of guest anions allowed a controllable angular modulation of a flexible vertex, facilitating the selective formation of irregular polyhedral structures (Figure 1(b)). Remarkably, the transformation between the cages containing a smaller anion and the relatively larger anions was found to be reversible, thus highlighting the impact of vertex flexibility on the structural tuning of cage assemblies.

\section{Results}

2.1. Design and Construction of the Flexible Vertex. Considering that vertex flexibility could result from the synergistic effect of coordination and covalent interactions, the ligand 1,4-di(pyridin-4-yl)buta-1,3-diyne (L) (Figure 2) was chosen owing to its reactive alkyne functionality towards the metal sulfide synthon $\left[\mathrm{Et}_{4} \mathrm{~N}\right]\left[T p^{*} \mathrm{WS}_{3}\right] \quad\left(T p^{*}=\operatorname{hydridotris}(3,5-\right.$ dimethylpyrazol-1-yl)borate) (A) (Figure 2) to generate a tetracoordinated building block of low symmetry $[36,46]$. During this reaction, $\mathbf{L}$ undergoes a significant configuration change and forms the new linker $\mathbf{L}^{\mathbf{a}}[36,46]$. The resulting 4coordinated building block binds with $\mathrm{Cu}(\mathrm{I})$ ions to form a new flexible vertex that can be used to construct unique supramolecular cages. In addition, the $\pi$-conjugated pyridyl moieties on ligand $\mathbf{L}$ can engender favorable $\mathrm{H}$-bonding and anion- $\pi$ interactions with guest anions [47-49]. Formation of these $\mathrm{H}$-bonding interactions and anion- $\pi$ interactions constitutes the driving force for regulating angular changes in the flexible vertex units.

2.2. Self-Assembly of the Distorted Tetrahedral Cage $[1]\left(B F_{4}\right)_{4}$. The reaction of the metal sulfide synthon $\mathbf{A}(1.0$ equiv), $\left[\mathrm{Cu}(\mathrm{MeCN})_{4}\right] \mathrm{BF}_{4}$ (2.0 equiv), and ligand $\mathbf{L}$ (1.0 equiv) in a mixed $\mathrm{CH}_{2} \mathrm{Cl}_{2} / \mathrm{MeCN}$ solvent yielded a severely distorted cationic tetrahedral cage of composition $\left[T p^{*}\right.$ $\left.\mathrm{WS}_{3} \mathrm{Cu}_{2}\left(\mathrm{~L}^{\mathbf{a}}\right)\right]_{4}\left(\mathrm{BF}_{4}\right)_{4}\left([\mathbf{1}]\left(\mathrm{BF}_{4}\right)_{4}\right)$ (Figures 2 and 3), as established by single-crystal X-ray diffraction (SCXRD). Its stoichiometry was further confirmed by electrospray ionization mass spectrometry (ESI-MS), with a peak at $\mathrm{m} / z=$ 1239.9343 with the correct isotopic distribution pattern for $\left\{[1]\left(\mathrm{BF}_{4}\right)\right\}^{3+}$ in $\mathrm{MeCN}$, indicating that cage $[1]\left(\mathrm{BF}_{4}\right)_{4}$ was stable in solution (Figure S1). Furthermore, diffusion-ordered NMR spectroscopy (DOSY) experiment on $[\mathbf{1}]\left(\mathrm{BF}_{4}\right)_{4}$ showed the presence of a discrete tetrahedral cage structure, with the single diffusion coefficient $\left(D=4.84 \times 10^{-10} \mathrm{~m}^{2} \mathrm{~s}^{-1}\right)$ (Figure S10). 


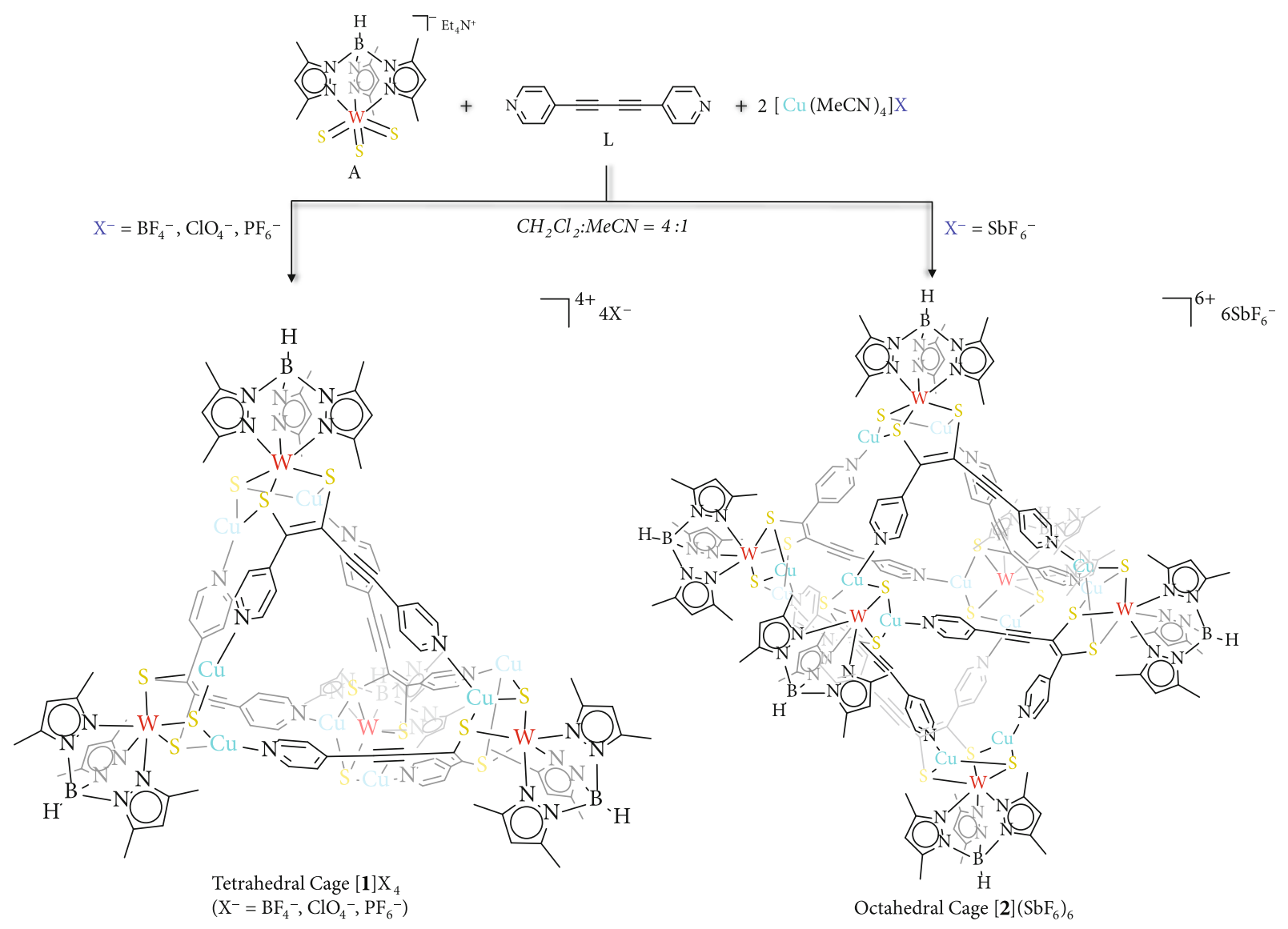

FIGURE 2: Schematic representation of the synthetic routes to the tetrahedral cage [2] and octahedral cage [2]. Treatment of the metal sulfide synthon $\left[\mathrm{Et}_{4} \mathrm{~N}\right]\left[\mathrm{Tp}^{*} \mathrm{WS}_{3}\right]$ (A) (1 equiv) with the ligand 1,4-di(pyridin-4-yl)buta-1,3-diyne (L) (1 equiv) and $\left[\mathrm{Cu}\left(\mathrm{MeCN}_{4}\right] \mathrm{X}\left(\mathrm{X}=\mathrm{BF}_{4}{ }^{-}\right.\right.$or $\mathrm{ClO}_{4}^{-}$or $\mathrm{PF}_{6}{ }^{-}$) (2 equiv) led to the formation of the framework of cationic distorted tetrahedral cage [2]. The framework of cationic distorted octahedral cage [2] formed from the reaction of subcomponents $\mathbf{A}$ and $\mathbf{L}$ together with $\left[\mathrm{Cu}(\mathrm{MeCN})_{4}\right] \mathrm{SbF}{ }_{6}$ in the same stoichiometry of $1: 1: 2$.

The SCXRD result reveals that $[1]\left(\mathrm{BF}_{4}\right)_{4}$ crystallizes in the triclinic space group $P \overline{1}$. As shown in Figure 3(a), one alkynyl group of $\mathbf{L}$ undergoes coupling with two $\mathrm{S}$ atoms on $\left[\mathrm{Tp}^{*} \mathrm{WS}_{3}\right]^{-}$to produce covalent interactions $(\mathrm{S}-\mathrm{C}=\mathrm{C}-\mathrm{S})$ in a 1,2-enedithiolato $\left[T p^{*} \mathrm{WS}_{3}\left(\mathbf{L}^{\mathbf{a}}\right)\right]^{-}$moiety, in which three coordination sites of the W (VI) center are occupied by the $T p^{*}$ and the octahedral coordination sphere is completed by three $\mathrm{S}$ atoms. This addition reaction resulted in a significant change of the geometry of $\mathbf{L}$ from linear to "boat" in the newly formed linker $\mathbf{L}^{\mathrm{a}}$. The remaining terminal $\mathrm{S}$ atom of $\mathbf{A}$ and two $\mathrm{S}(\mathrm{S}-\mathrm{C}=\mathrm{C}-\mathrm{S})$ atoms are available for binding with two $\mathrm{Cu}(\mathrm{I})$ ions, thus forming the $\left[T p^{*} \mathrm{WS}_{3} \mathrm{Cu}_{2}\left(\mathbf{L}^{\mathbf{a}}\right)\right]^{+}$ moiety that can be regarded as a single "vertex" (Figure 3(b)). Both $\mathrm{Cu}(\mathrm{I})$ ions on the $\left[T p^{*} \mathrm{WS}_{3} \mathrm{Cu}_{2}\left(\mathrm{~L}^{\mathbf{a}}\right)\right]^{+}$ vertex further bind to the pyridine donor of $\mathbf{L}^{\mathbf{a}}$ extending from other $\left[T p^{*} \mathrm{WS}_{3} \mathrm{Cu}_{2}\left(\mathbf{L}^{\mathbf{a}}\right)\right]^{+}$units via coordination interactions. The coexistence of coordination and covalent interactions in one connector lowers the symmetry of the vertex and renders the resulting supramolecular architectures dissymmetrical and distorted. The interligand angle $\alpha$ in the $\left[T^{*} \mathrm{WS}_{3} \mathrm{Cu}_{2}\left(\mathbf{L}^{\mathbf{a}}\right)\right]^{+}$vertex is of approximately $42.5^{\circ}$ (Figure 3(b)). The four connections extend out of the $\left[T p^{*} \mathrm{WS}_{3} \mathrm{Cu}_{2}\left(\mathbf{L}^{\mathbf{a}}\right)\right]^{+}$unit, but it is clear that the two short connections, involving both a pyridyl donor and acceptor, are directed towards a single $\left[T p^{*} \mathrm{WS}_{3} \mathrm{Cu}_{2}\left(\mathbf{L}^{\mathbf{a}}\right)\right]^{+}$ unit, which further links only three other chemically similar, but crystallographically distinct $\left[T p^{*} \mathrm{WS}_{3} \mathrm{Cu}_{2}\left(\mathbf{L}^{\mathbf{a}}\right)\right]^{+}$ units. This results in a severely distorted, dissymmetrical tetrahedral cage (Figure 3(c) and 3(d)) possessing an unprecedented topology (Figure 3(e)). This dissymmetrical character results in a chiral tetrahedral structure (Figure S22), but the enantiomeric cages crystallize in a $1: 1$ stoichiometry (Figure S23) to form a racemic conglomerate.

The internal $\mathrm{BF}_{4}^{-}$anion in the tetrahedral cage [1] fits snugly within the hollow (Figure 3(c)), which suggests that the internal anion plays an important templating role in the formation of the tetrahedral cage. It is found to associate with the tetrahedral host in which the $\mathrm{F}$ atoms interact with the close $\mathrm{H}$ atoms of adjacent pyridine rings on the $\mathbf{L}^{\mathbf{a}}$ linker, forming $\mathrm{H}$-bonding interactions, with the primary $\mathrm{C}-\mathrm{H} \cdots \mathrm{F}$ distances in the range of $2.61-2.87 \AA$ (Figure S24A). Furthermore, it is engaged in typical anion- $\pi$ contacts in which the $\mathrm{F}$ atoms interact with the $\mathrm{C}$ atoms on the pyridine rings, establishing the directional $\mathrm{F} \cdots \mathrm{C}_{\text {pyridine }}$ 


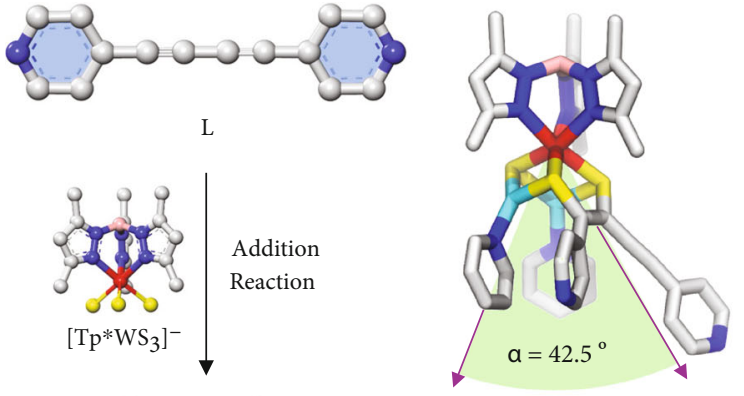

(b)

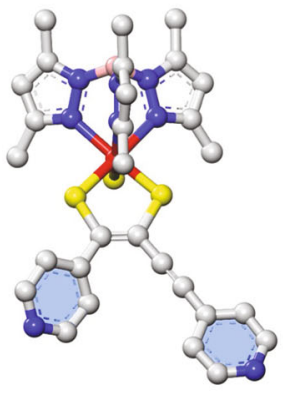

$\left[\mathrm{Tp}^{*} \mathrm{WS}_{3}\left(\mathrm{~L}^{\mathrm{a}}\right)\right]^{-}$

(a)

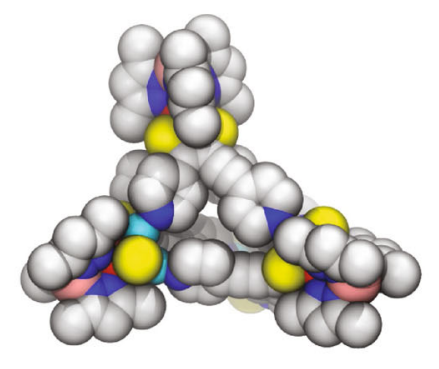

(d)

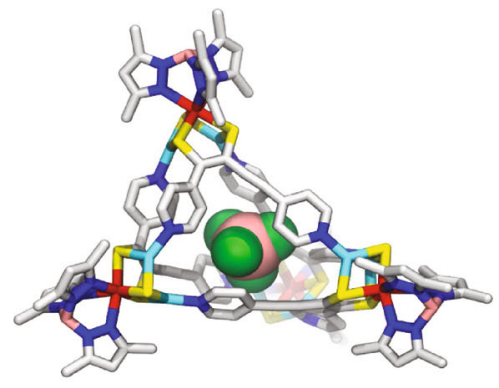

(c)

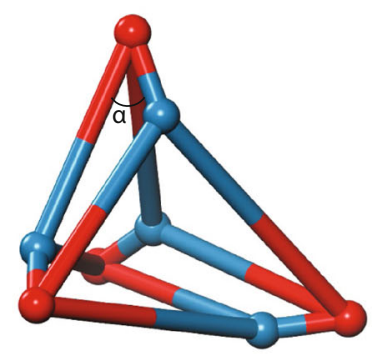

(e)

FIgURE 3: Single-crystal X-ray structure of the tetrahedral cage [1]. (a) View of the structure of the $\left[\mathrm{Tp}^{*} \mathrm{WS}_{3}\left(\mathrm{~L}^{\mathbf{a}}\right)\right]^{-}$moiety from addition reaction between ligand $\mathbf{L}$ and the metal sulfide synthon $\left[\mathrm{Et}_{4} \mathrm{~N}\right]\left[\mathrm{Tp}^{*} \mathrm{WS}_{3}\right](\mathbf{A})$, producing $\mathrm{S}-\mathrm{C}=\mathrm{C}-\mathrm{S}$ covalent interaction. (b) View of the vertex of [1] with a small angle of $\alpha$ being $42.5^{\circ}$. (c) View of the whole structure of the distorted cationic tetrahedral cage [1] with a space-filling model representation of the one templating $\mathrm{BF}_{4}{ }^{-}$anion included. (d) View of the space-filling model representation of [1]. (e) Topology of [1]. The angle of $\alpha$ marked here corresponds to the angle of vertex in Figure 3(b). The red balls and cyan balls, respectively, stand for the $T p^{*} \mathrm{WS}_{3}$ unit and reacted alkynyl ligand $\mathbf{L}^{\mathbf{a}}$ units. Color codes: W (red), Cu (azure), S (yellow), $\mathrm{N}$ (blue), C (silver), B (light salmon), and F (green). In all views, all hydrogen atoms, the nonencapsulated anions, solvent molecules, and disorder are omitted for clarity.

contacts in the range of 3.07-3.45 (Figure S24B). The above close-contact analysis of cage $[\mathbf{1}]\left(\mathrm{BF}_{4}\right)_{4}$ shows that the framework of tetrahedral host is well stabilized by $\mathrm{H}$-bonding and $\mathrm{F}-\pi$ interactions between the pyridyl moieties and the encapsulated $\mathrm{BF}_{4}^{-}$.

2.3. Impact of Guest Anions on the Angular Changes in a Flexible Vertex. The host-guest interactions between the internal $\mathrm{BF}_{4}{ }^{-}$and the tetrahedral host [1] indicate that this guest anion acts as a competent template in the selfassembly process and the larger anions may generate similar interactions with the $\left[T p^{*} \mathrm{WS}_{3} \mathrm{Cu}_{2}\left(\mathrm{~L}^{\mathbf{a}}\right)\right]^{+}$units and influence the angle $\alpha$ at the node, thereby possibly realizing a finetuning of supramolecular cage geometries. To verify this assumption, three other anions with increasing volume, oxyanion perchlorate $\left(\mathrm{ClO}_{4}^{-}\right)$, hexafluorophosphate $\left(\mathrm{PF}_{6}^{-}\right)$and hexafluoroantimonate $\left(\mathrm{SbF}_{6}{ }^{-}\right)$were adopted. Using similar reaction conditions as for $[\mathbf{1}]\left(\mathrm{BF}_{4}\right)_{4}$, two isostructural tetrahedral assemblies $[\mathbf{1}]\left(\mathrm{ClO}_{4}\right)_{4}$ (Figure S25A) and $[\mathbf{1}]\left(\mathrm{PF}_{6}\right)_{4}$ (Figure S25B) were obtained, respectively, with the value for the angle $\alpha$ in the vertex approximately equal to that in the counterpart in $[\mathbf{1}]\left(\mathrm{BF}_{4}\right)_{4}$ (Figure S26). Each tetrahedral cage encapsulates one $\mathrm{ClO}_{4}{ }^{-}$or one $\mathrm{PF}_{6}{ }^{-}$within its cavity, and similar host-guest interactions are also observed as described in $[\mathbf{1}]\left(\mathrm{BF}_{4}\right)_{4}$ (Figure S27 and Figure S28). Interestingly, when the larger anion $\mathrm{SbF}_{6}{ }^{-}$was employed, a cationic octahedral assembly $\left[T p^{*} \mathrm{WS}_{3} \mathrm{Cu}_{2}\left(\mathbf{L}^{\mathbf{a}}\right)\right]_{6}\left(\mathrm{SbF}_{6}\right)_{6}$
$\left([2]\left(\mathrm{SbF}_{6}\right)_{6}\right)$ (Figure 2 and Figure $\mathrm{S} 30$ ) was isolated, which crystallized in the trigonal space group $R \overline{3}$. The above solid compounds had good thermal stability (Figure S31) confirmed by the thermogravimetric analyses (TGA), and the octahedral compound $[2]\left(\mathrm{SbF}_{6}\right)_{6}$ exhibited higher thermal stability than the tetrahedral compounds.

In the octahedral cage [2], although the $\left[T p^{*}\right.$ $\left.\mathrm{WS}_{3} \mathrm{Cu}_{2}\left(\mathbf{L}^{\mathbf{a}}\right)\right]^{+}$unit serves as a 4 -connector and as a structural vertex, the angle $\alpha$ is dramatically increased to $69.8^{\circ}$ (Figure 4 and Figure S30C). This nicely validates our speculation that the $\left[T p^{*} \mathrm{WS}_{3} \mathrm{Cu}_{2}\left(\mathrm{~L}^{\mathbf{a}}\right)\right]^{+}$unit functions as a versatile vertex that is able to stretch its interligand angles ranging from $42.5^{\circ}$ to $69.8^{\circ}$ in response to the large $\mathrm{SbF}_{6}{ }^{-}$ anions. The vertexes containing the angle $\alpha$ being $69.8^{\circ}$ allow to be splayed apart from each other permitting connections to four rather than three equivalent units, thus leading to a low symmetry cage of distorted octahedral geometry (Figure S30D). This exemplifies the real possibility of controlling the assembled structure through adjusting the angle at a flexible vertex.

Inspecting the cavity of the octahedral cage [2] shows that there is one pair of $\mathrm{SbF}_{6}{ }^{-}$anions (Figure S30A). Each $\mathrm{Sb}(\mathrm{V})$ center is located just off a 3 -fold axis that passes through the cage. In addition to the positional disorder, the internal anions exhibit considerable orientational disorder (only one orientation is shown in Figure S30A, Figure S32, and Figure S33). Despite this disorder, it is 


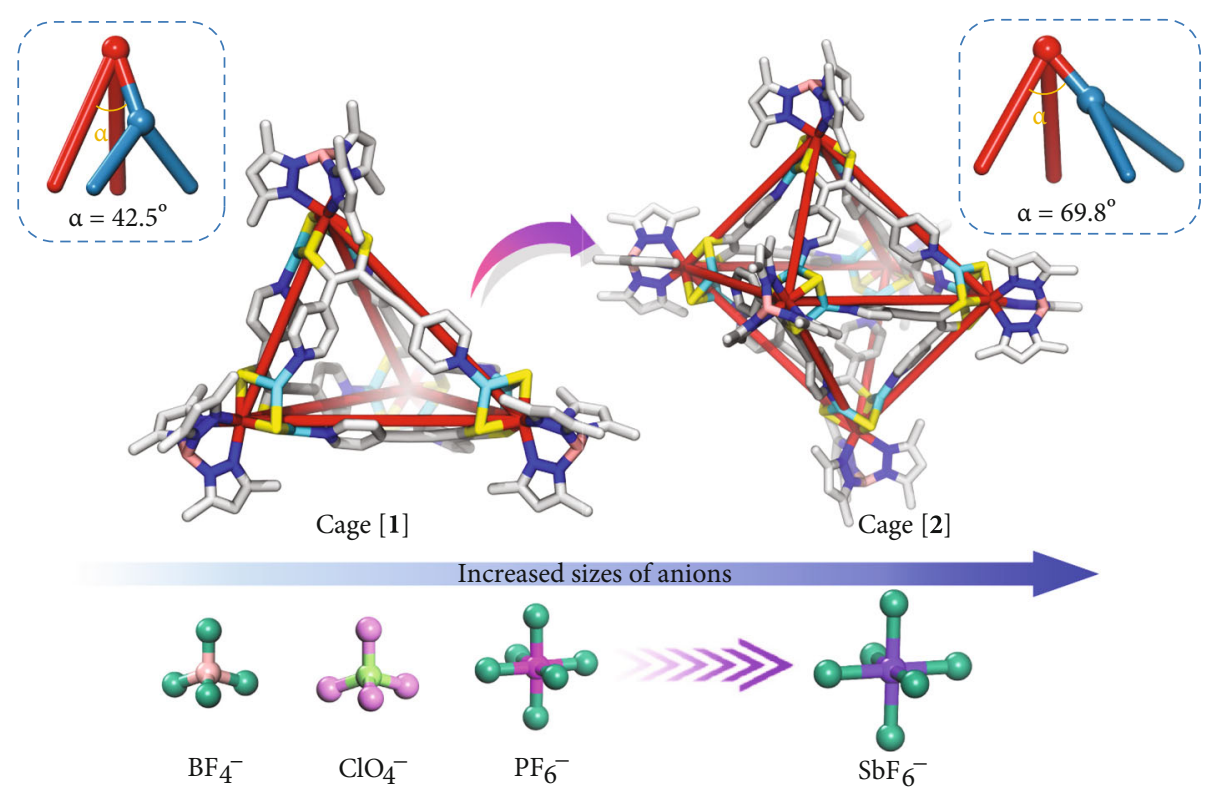

FIGURE 4: Illustration of the controllable formation of tetrahedral cage [1] and octahedral cage [2] by regulating the angle at a flexible vertex by the change of the anion size. The smaller anions including $\mathrm{BF}_{4}^{-}, \mathrm{ClO}_{4}^{-}$, and $\mathrm{PF}_{6}^{-}$favor to the formation of the small-angle vertex with approximately $42.5^{\circ}$, generating highly distorted tetrahedral cage [1]. When the size of the anion further increases from $\mathrm{PF}_{6}{ }^{-}$to $\mathrm{SbF}_{6}{ }^{-}$, the angle of the flexible vertex significantly opens to $69.8^{\circ}$, thus causing the structural transition from the tetrahedral cage [1] to distorted octahedral cage [2].

apparent that the $\mathrm{F}$ atoms establish a rather close contact with the aromatic surfaces. Both encapsulated $\mathrm{SbF}_{6}{ }^{-}$anions develop hydrogen bonding contacts with the pyridyl $\mathrm{H}$ atoms, with the primary $\mathrm{C}-\mathrm{H}$... F distances being 2.08$2.97 \AA$ (Figure S33A). In addition, the $\mathrm{C}$ atoms of the linker $\mathrm{L}^{\mathbf{a}}$ also establish directional $\mathrm{F}$... $\mathrm{C}_{\text {pyridine }}$ contacts with the $\mathrm{F}$ atoms of the $\mathrm{SbF}_{6}{ }^{-}$anions with the primary distances being 3.12-3.60 $\AA$ (Figure S33B). Interestingly, the pyridyl group of the linker $\mathbf{L}^{\mathbf{a}}$ in $[2]\left(\mathrm{SbF}_{6}\right)_{6}$ is oriented in such a way that the hydrogen atoms of the pyridyl group are pointing inwards in a configuration that results in the $\mathrm{C}$ $-\mathrm{H} \cdots \mathrm{F}$ contacts. Examination of each structure suggests that the angle at the vertex could be adjusted in a controlled manner, adapting to the changes of the size of guest anions. When the size of guest anions increases from $\mathrm{BF}_{4}^{-}, \mathrm{ClO}_{4}^{-}, \mathrm{PF}_{6}{ }^{-}$to $\mathrm{SbF}_{6}{ }^{-}$, the angle in the metal vertex drastically expands from $42.5^{\circ}$ to $69.8^{\circ}$, resulting in the structural transition from the tetrahedral cage [1] to the octahedral cage [2] (Figure 4).

2.4. Reversible Structural Transformation between [1] and [2]. The anion-dependent formation of the tetrahedral and octahedral assemblies encouraged us to explore their interconversion starting from the respective pure entities. We speculated that a change of the anion might result in a unique reversible conversion between tetrahedral [1] and octahedral cages [2]. After dissolution of the octahedral cage compound [2] $\left(\mathrm{SbF}_{6}\right)_{6}$ in $\mathrm{MeCN}$ (Figure $5(\mathrm{a})$ ), an excess of $\left({ }^{\mathrm{n}} \mathrm{Bu}_{4} \mathrm{~N}\right)\left(\mathrm{BF}_{4}\right)$ was added to the MeCN solution stirring for $8 \mathrm{~h}$ at ambient temperature. ESI-MS analysis revealed a new peak at $\mathrm{m} / z$ 1239.9617, assigned to the tetrahedral cage $\left\{[1]\left(\mathrm{BF}_{4}\right)\right\}^{3+}$ with the correct isotopic distribution (Figure 5(b)). This demon- strated that introduction of small $\mathrm{BF}_{4}{ }^{-}$anions to a solution of the octahedral cage compound [2] induces its transformation to the tetrahedral cage [1]. However, when we introduced excess $\left(\mathrm{Et}_{4} \mathrm{~N}\right)\left(\mathrm{SbF}_{6}\right)$ to the tetrahedral $[\mathbf{1}]\left(\mathrm{BF}_{4}\right)_{4}$ system, no any octahedral cage [2] signal (Figure S34) was observed, indicating no cage transformation took place. Intriguingly, upon addition of $\mathrm{HSbF}_{6}$ and $\mathrm{NEt}_{3}$ to a solution of $[\mathbf{1}]\left(\mathrm{BF}_{4}\right)_{4}$, we did observe the structural transformation of the tetrahedral cage [1] to the octahedral cage [2] by ESI-MS. One signal at $m / z 1475.2583$ can be assigned to be the octahedral cage $\left\{[2]\left(\mathrm{SbF}_{6}\right)(\mathrm{Cl}) \cdot 10 \mathrm{H}_{2} \mathrm{O}\right\}^{4+}$ (Figures 5(c) and 5(d)). The results demonstrate aniondirected reversible transformation between the tetrahedral cage [1] and the octahedral cage [2] and further validate the concept of flexible building block where the angle at the vertex is capable of adjusting to the nature of the anion present, to give the preferred cage structure.

2.5. Investigation of Third-Order Nonlinear Optical (NLO) Properties. The rigid skeletons of the above cage assemblies hold multiple heavy metal atoms and highly $\pi$-conjugated organic linkers, which inspired us to explore their thirdorder nonlinear optical (NLO) properties [36, 50]. The third-order NLO properties of KBr-based thin films of $\mathbf{A}$, $[1]\left(\mathrm{BF}_{4}\right)_{4}$, and $[2]\left(\mathrm{SbF}_{6}\right)_{6}$ prepared by a table pressing method and their DMF solutions $\left(1.38 \times 10^{-4} \mathrm{~mol} / \mathrm{L}\right)$ were measured, respectively, by a typical open aperture Z-scan technique at $532 \mathrm{~nm}$ with a nanosecond pulsed (4ns) laser under the similar incident pulse energy. Both cage compounds had deep valleys at zero point (focal point of lens), indicating an interesting reverse saturable absorption (RSA) response [51] either in solution or in an aggregated 


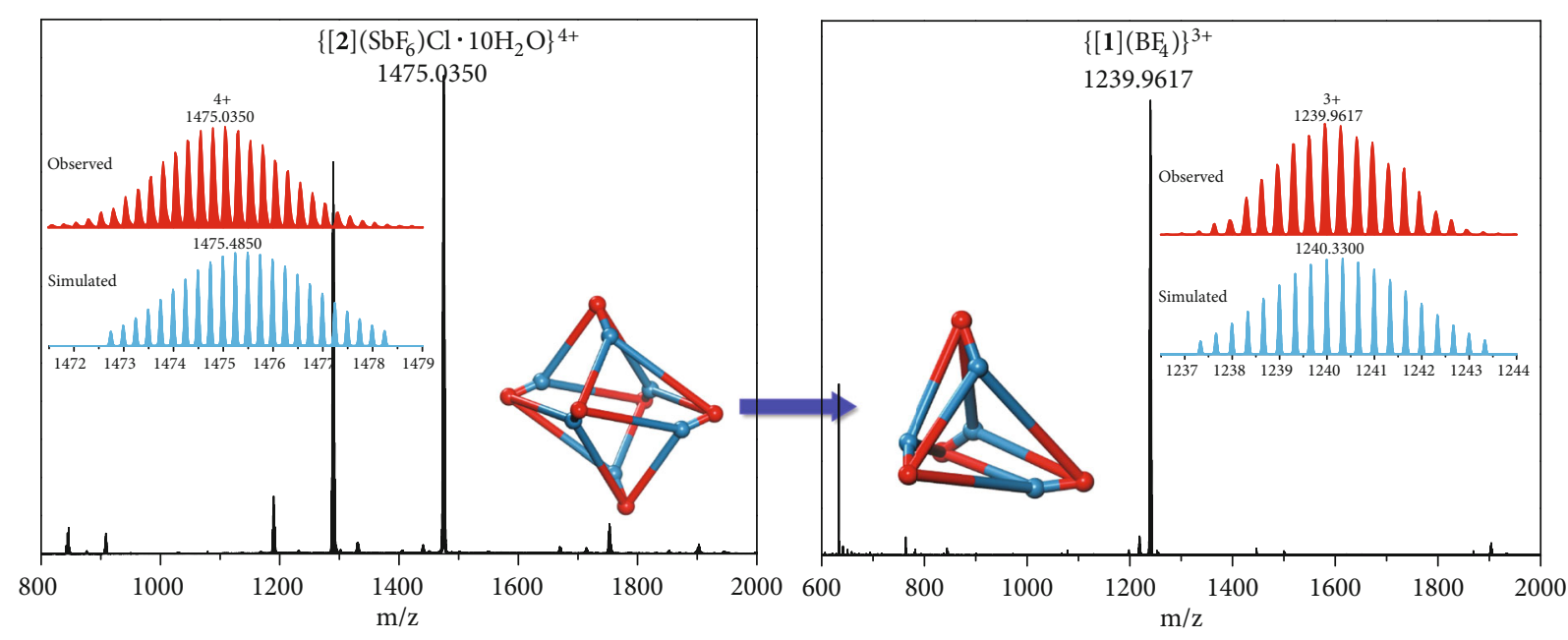

(a)

(b)

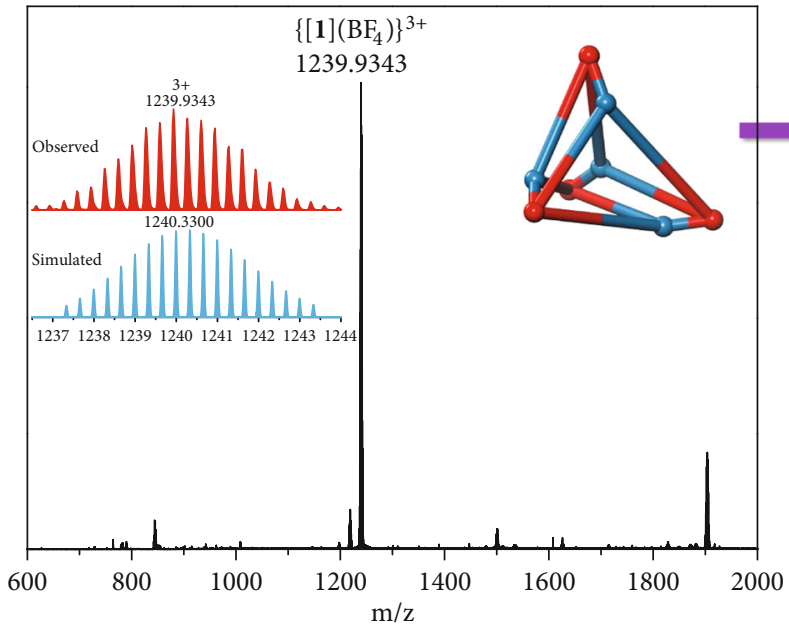

(c)

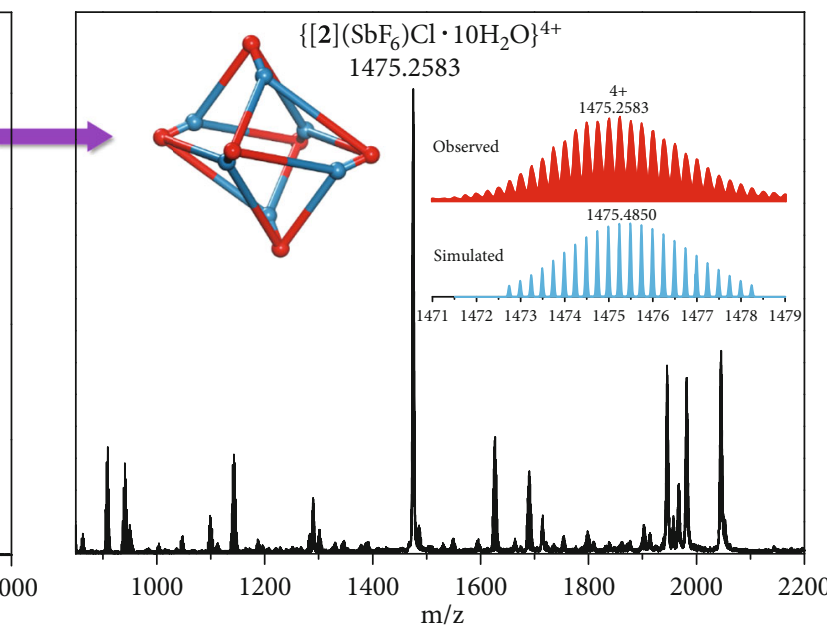

(d)

FIGURE 5: Monitoring the structural transformations between tetrahedral cage [1] and octahedral cage [2]. (a) ESI-MS spectrum of the pure octahedral compound $[2]\left(\mathrm{SbF}_{6}\right)_{6}$ in $\mathrm{MeCN}$ before addition of $\left({ }^{\mathrm{n}} \mathrm{Bu}_{4} \mathrm{~N}\right)\left(\mathrm{BF}_{4}\right)$. (b) ESI-MS spectrum after addition of excess $\left({ }^{\mathrm{n}} \mathrm{Bu}_{4} \mathrm{~N}\right)\left(\mathrm{BF}{ }_{4}\right)$ successfully monitoring the appearance of the tetrahedral cage [1] at $\mathrm{m} / z$ 1239.9617. (c) ESI-MS spectrum of the pure tetrahedral compound $[1]\left(\mathrm{BF}_{4}\right)_{4}$ in MeCN.(d) ESI-MS spectrum after addition of $\mathrm{HSbF}_{6}$ and $\mathrm{NEt}_{3}$ successfully monitoring the appearance of the octahedral cage [2] at $\mathrm{m} / z$ 1475.2583.

state of the $\mathrm{KBr}$-based thin films (Figure 6). But for pure DMF solvent, pure $\mathrm{KBr}$ thin film, $\mathbf{A}$ in $\mathrm{DMF}$, and $\mathbf{A} / \mathrm{KBr}$ thin film, they show no detectable absorption signals (Figures S37S40). Thus, the third-order NLO responses could result from the tetrahedral or octahedral cages. Both $[1]\left(\mathrm{BF}_{4}\right)_{4}$ and [2] $\left(\mathrm{SbF}_{6}\right)_{6}$ in DMF showed a very weak RSA signal with the effective nonlinear absorption coefficient $\beta$ [52] of $1.1 \times$ $10^{-11} \mathrm{~m} / \mathrm{W}$ and $1.8 \times 10^{-11} \mathrm{~m} / \mathrm{W}$, respectively. However, the NLO responses of their $\mathrm{KBr}$-based thin films were sharply enhanced, with their corresponding $\beta$ values being $7.0 \times$ $10^{-9} \mathrm{~m} / \mathrm{W}$ for $[1]\left(\mathrm{BF}_{4}\right)_{4} / \mathrm{KBr}$ thin film and $2.1 \times 10^{-8} \mathrm{~m} / \mathrm{W}$ for $[2]\left(\mathrm{SbF}_{6}\right)_{6} / \mathrm{KBr}$ thin film, which are 636 and 1167 times larger than those of their corresponding solutions (Table S2) and better than that of $\left[\left(\mathrm{C}_{4} \mathrm{H}_{9}\right)_{4}\right]_{2}\left[\mathrm{Cu}\left(\mathrm{C}_{3} \mathrm{~S}_{5}\right)_{2}\right]$-doped polymethylmethacrylate (PMMA) thin film [53]. Similar Zscan results for $[1]\left(\mathrm{ClO}_{4}\right)_{4}$ (Figure S41 and Table S2) and $[1]\left(\mathrm{PF}_{6}\right)_{4}$ (Figure S42 and Table S2) were also obtained. Such an outstanding enhancement of the NLO performances could be due to doping concentrations in the $\mathrm{KBr}$ films being much larger than those of solution. The difference between the $\mathrm{KBr}$-based tetrahedral and octahedral films may be ascribed to the increase of $\mathrm{W} / \mathrm{Cu} / \mathrm{S}$ cluster cores and the structural expansion from a tetrahedral cage to an octahedral cage. In addition, the third-order NLO response could be gradually improved by increasing the concentrations of $[\mathbf{1}]\left(\mathrm{BF}_{4}\right)_{4}$ and $[2]\left(\mathrm{SbF}_{6}\right)_{6}$ in DMF by 1.5 times $\left(2.07 \times 10^{-4}\right.$ $\mathrm{mol} / \mathrm{L}$ ) and 2 times $\left(2.76 \times 10^{-4} \mathrm{~mol} / \mathrm{L}\right.$ ) (Figure S43, Figure S44, and Table S2).

\section{Discussion}

We have demonstrated that taking advantage of a flexible vertex with adjustable angles represents a feasible and promising strategy for creating new cage assemblies. Using this 


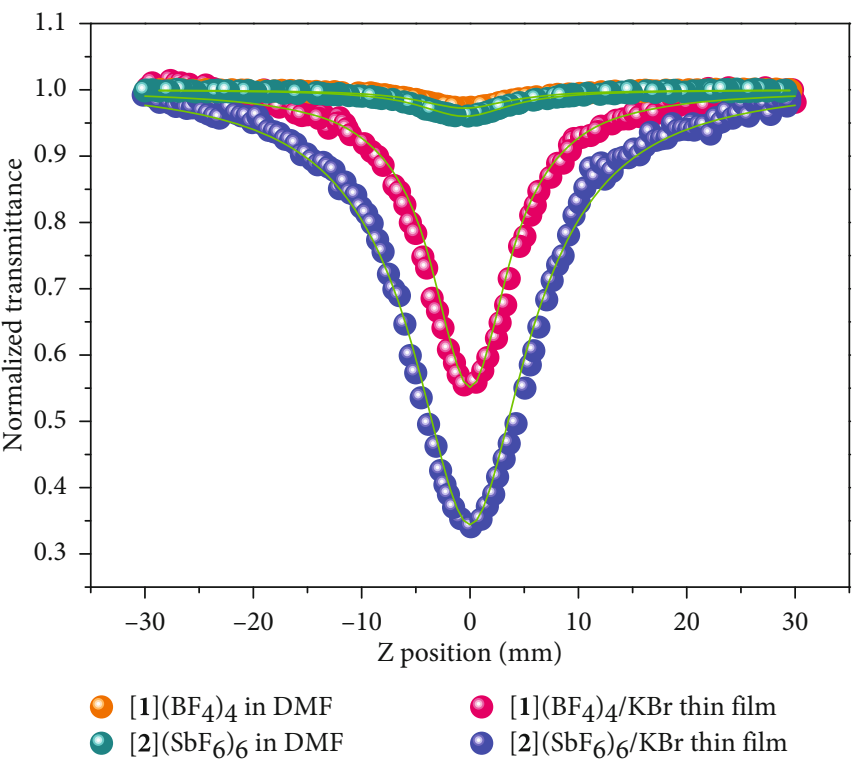

(a)
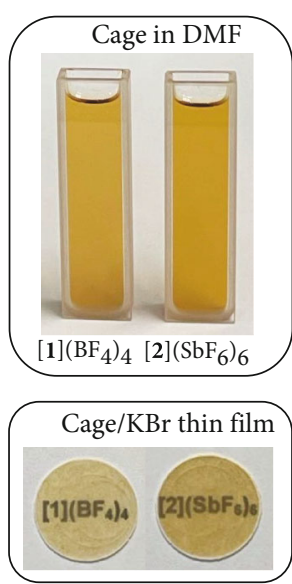

(b)

FIgure 6: Third-order NLO properties of the $\mathrm{KBr}$-based thin films of $[\mathbf{1}]\left(\mathrm{BF}_{4}\right)_{4}$ and $[2]\left(\mathrm{SbF}_{6}\right)_{6}$ and their DMF solutions. The orange, dark cyan, pink, and blue spheres represent the experimental data of $[1]\left(\mathrm{BF}_{4}\right)_{4}$ in $\mathrm{DMF},[2]\left(\mathrm{SbF}_{6}\right)_{6}$ in $\mathrm{DMF},[1]\left(\mathrm{BF}_{4}\right)_{4} / \mathrm{KBr}$ thin film, and $[2]\left(\mathrm{SbF}_{6}\right)_{6} / \mathrm{KBr}$ thin film, respectively, and the green solid curves represent the theoretical fit by Bahae et al.'s theory [52]. The insets in (b) are photo of the samples of $[1]\left(\mathrm{BF}_{4}\right)_{4}$ and $[2]\left(\mathrm{SbF}_{6}\right)_{6}$ in DMF and $\mathrm{KBr}$-based cage thin films.

approach, two kinds of cages, highly distorted tetrahedral and distorted octahedral cages, have been constructed. Relatively small guest anions $\left(\mathrm{BF}_{4}^{-}, \mathrm{ClO}_{4}^{-}\right.$, and $\left.\mathrm{PF}_{6}{ }^{-}\right)$favor the formation of the small-angle vertex and trigger the generation of the highly distorted tetrahedral cages, whereas the larger $\mathrm{SbF}_{6}{ }^{-}$anions increase the angle of the vertex and thus lead to the formation of distorted octahedral cages. The structures of these two types of supramolecular cages with host-guest interactions were demonstrated by detailed $\mathrm{X}$-ray crystallography studies. Furthermore, the reversible topological transformation between these cages induced by the presence of different anions was demonstrated by ESI-MS technique. Finally, a significant amplification of the third-order NLO responses of both types of cages was realized by engineering them in $\mathrm{KBr}$-based thin films, when compared to those of their solutions. This work provides a readily accessible access to topologically irregular polyhedral edifices, demonstrates anion-triggered reversible conversion between tetrahedral and octahedral cages, and paves the way for the development of new optical components.

\section{Materials and Methods}

4.1. Chemicals and Reagents. All reagents and solvents were purchased from commercial sources and used as supplied unless otherwise mentioned. The starting materials $\left[\mathrm{Et}_{4} \mathrm{~N}\right]\left[T p^{*} \mathrm{WS}_{3}\right]$ (A) $\left(T p^{*}=\right.$ hydridotris(3,5-dimethylpyrazol-1-yl)borate) [54] and the ligand 1,4-di(pyridin-4yl)buta-1,3-diyne (L) [55] were prepared by literature methods.

4.2. Physical Characterizations. Elemental analyses (C, H, and $\mathrm{N}$ ) were performed on a Carlo-Erba CHNO-S microan- alyzer. Fourier-transform infrared (IR) spectra of the solid samples (KBr tablets) in the range $400-4000 \mathrm{~cm}^{-1}$ were recorded on a Varian 1000 spectrometer. Thermogravimetric analyses (TGA) were performed on a Mettler Toledo Star System under a nitrogen atmosphere at a heating rate of $10^{\circ} \mathrm{Cmin}^{-1}$. UV-Vis spectra were recorded on a Varian Cary-50 UV-Vis spectrophotometer. The solid samples used for elemental analysis and TGA analysis were dried overnight at $80^{\circ} \mathrm{C}$ in a vacuum oven for removing solvent molecules. ${ }^{1} \mathrm{H}$ NMR spectra and ${ }^{13} \mathrm{C}$ NMR spectra of the ligand $\mathbf{L}$ were recorded on BRUKER AVANCE III HD $(400 \mathrm{MHz})$ at room temperature and referenced to the residual protonated solvent for NMR spectra. ${ }^{1} \mathrm{H}$ NMR spectra, ${ }^{1} \mathrm{H}-{ }^{1} \mathrm{H}$ COSY spectra, and ${ }^{1} \mathrm{H}$ DOSY spectra of $[\mathbf{1}]\left(\mathrm{BF}_{4}\right)_{4},[\mathbf{1}]\left(\mathrm{ClO}_{4}\right)_{4}$, $[\mathbf{1}]\left(\mathrm{PF}_{6}\right)_{4}$, and $[2]\left(\mathrm{SbF}_{6}\right)_{6}$ were recorded on a Varian UNITY plus-600 spectrometer at room temperature and referenced to the residual protonated solvent for NMR spectra. Proton chemical shift $\delta \mathrm{H}=7.26\left(\mathrm{CDCl}_{3}\right)$ and $\delta \mathrm{H}=1.94\left(\mathrm{CD}_{3} \mathrm{CN}\right)$ were reported relative to the solvent residual peak. ESITOF MS spectra of $[1]\left(\mathrm{BF}_{4}\right)_{4},[\mathbf{1}]\left(\mathrm{ClO}_{4}\right)_{4},[1]\left(\mathrm{PF}_{6}\right)_{4}$, and $[2]\left(\mathrm{SbF}_{6}\right)_{6}$ were recorded on a Bruker micrOTOF-Q III mass spectrometer.

4.3. Synthesis of 1,4-Di(pyridin-4-yl)buta-1,3-diyne (L). According to the literature procedure [55], ligand $\mathbf{L}$ was synthesized as follows. A suspension of copper (I) iodide (250 mg, $1.25 \mathrm{mmol})$, nickel (II) chloride hexahydrate (300 $\mathrm{mg}, \quad 1.25 \mathrm{mmol})$, and tetramethylethylenediamine (TMEDA) $(0.75 \mathrm{~mL}, 5.0 \mathrm{mmol})$ in $120 \mathrm{~mL}$ of anhydrous THF was stirred under an inert atmosphere $\left(\mathrm{N}_{2}\right)$ for $10 \mathrm{~min}$. Then, 4-ethynylpyridine $(5000 \mathrm{mg}, 50.0 \mathrm{mmol})$ was added, and the mixture was stirred at room temperature over a period of $4 \mathrm{~h}$ while air was bubbled through the mixture. After 
evaporation of the solvent, the resulting residue was chromatographed on silica gel (petroleum ether : ethyl acetate $=10: 1$ ) to give a colorless solid L: $204 \mathrm{mg}$ (99\%).

4.4. Synthesis of $[\mathbf{1}]\left(\mathrm{BF}_{4}\right)_{4}$. $\mathrm{A} \mathrm{CH}_{2} \mathrm{Cl}_{2} / \mathrm{MeCN}(40 \mathrm{~mL} / 10 \mathrm{~mL})$ solution of $\left[\mathrm{Et}_{4} \mathrm{~N}\right]\left[\mathrm{Tp}^{*} \mathrm{WS}_{3}\right]$ (A) $(0.071 \mathrm{~g}, 0.10 \mathrm{mmol})$, $\left[\mathrm{Cu}(\mathrm{MeCN})_{4}\right] \mathrm{BF}_{4}(0.063 \mathrm{~g}, 0.20 \mathrm{mmol})$, and $\mathbf{L}(0.020 \mathrm{~g}$, $0.10 \mathrm{mmol}$ ) was stirred for $6 \mathrm{~h}$ under ambient temperature. Then, the solution was filtered, and diethyl ether was carefully layered onto the filtrate to generate red crystals in about one week. The product was isolated and characterized as indicated in the Supplementary Materials.

4.5. Synthesis of $[\mathbf{1}]\left(\mathrm{ClO}_{4}\right)_{4}$. The synthesis method was consistent with that of compound $[\mathbf{1}]\left(\mathrm{BF}_{4}\right)_{4}$. Compound $[\mathbf{1}]\left(\mathrm{ClO}_{4}\right)_{4}$ was obtained by substituting $\left[\mathrm{Cu}(\mathrm{MeCN})_{4}\right] \mathrm{BF}_{4}$ $(0.063 \mathrm{~g}, \quad 0.20 \mathrm{mmol})$ for $\left[\mathrm{Cu}(\mathrm{MeCN})_{4}\right] \mathrm{ClO}_{4} \quad(0.066 \mathrm{~g}$, $0.20 \mathrm{mmol})$. The product was isolated and characterized as indicated in the Supplementary Materials.

4.6. Synthesis of $[\mathbf{1}]\left(\mathrm{PF}_{6}\right)_{4}$. The synthesis method was similar to that for $[1]\left(\mathrm{BF}_{4}\right)_{4}$. Compound $[1]\left(\mathrm{PF}_{6}\right)_{4}$ was obtained by substituting $\left[\mathrm{Cu}(\mathrm{MeCN})_{4}\right] \mathrm{BF}_{4} \quad(0.063 \mathrm{~g}, 0.20 \mathrm{mmol})$ for $\left[\mathrm{Cu}(\mathrm{MeCN})_{4}\right] \mathrm{PF}_{6}(0.075 \mathrm{~g}, 0.20 \mathrm{mmol})$. The product was isolated and characterized as indicated in the Supplementary Materials.

4.7. Synthesis of $[2]\left(\mathrm{SbF}_{6}\right)_{6}$. The synthesis method was similar to that of compound $[1]\left(\mathrm{BF}_{4}\right)_{4}$. Compound $[2]\left(\mathrm{SbF}_{6}\right)_{6}$ was obtained by substituting $\left[\mathrm{Cu}(\mathrm{MeCN})_{4}\right] \mathrm{BF}_{4}(0.063 \mathrm{~g}$, $0.20 \mathrm{mmol})$ for $\left[\mathrm{Cu}(\mathrm{MeCN})_{4}\right] \mathrm{SbF}_{6}(0.093 \mathrm{~g}, 0.20 \mathrm{mmol})$. The product was isolated and characterized as indicated in the Supplementary Materials.

4.8. Structural Transformation from the Octahedral Cage [2] to the Tetrahedral Cage [1]. Upon dissolution of crystals of $[2]\left(\mathrm{SbF}_{6}\right)_{6}\left(0.006 \mathrm{~g}, 8.7 \times 10^{-4} \mathrm{mmol}\right)$ in $2 \mathrm{~mL} \mathrm{MeCN}$, an excess of $\left({ }^{\mathrm{n}} \mathrm{Bu}_{4} \mathrm{~N}\right)\left(\mathrm{BF}_{4}\right)\left(0.003 \mathrm{~g}, 9.4 \times 10^{-3} \mathrm{mmol}\right)$ was added to the $\mathrm{MeCN}$ solution of $[2]\left(\mathrm{SbF}_{6}\right)_{6}$ and stirring was maintained for $8 \mathrm{~h}$ at ambient temperature. The solution was then analyzed by ESI-MS, and a new signal was observed at $\mathrm{m} / \mathrm{z}$ 1239.9617 with the correct isotopic distribution patterns for the tetrahedral cage $\left\{[\mathbf{1}]\left(\mathrm{BF}_{4}\right)\right\}^{3+}$. The results suggested that a structural transformation from the octahedral cage [2] to the tetrahedral cage [1] has resulted from the introduction of excess $\mathrm{BF}_{4}{ }^{-}$anions.

4.9. Structural Transformation from the Tetrahedral Cage [1] to the Octahedral Cage [2]. Upon dissolution of crystals of $[1]\left(\mathrm{BF}_{4}\right)_{4}\left(0.004 \mathrm{~g}, 1.0 \times 10^{-3} \mathrm{mmol}\right)$ in $0.5 \mathrm{~mL} \mathrm{MeCN}$, $\mathrm{HSbF}_{6}(0.004 \mathrm{~g}, 0.016 \mathrm{mmol})$ in $1.5 \mathrm{~mL} \mathrm{MeCN}$ was added to the MeCN solution of $[1]\left(\mathrm{BF}_{4}\right)_{4}$ and stirring was maintained for $2 \mathrm{~h}$ at ambient temperature. Then, $\mathrm{NEt}_{3}(0.002 \mathrm{~g}$, $0.020 \mathrm{mmol}$ ) in $0.5 \mathrm{~mL} \mathrm{MeCN}$ was added to the reaction mixture which was further stirred for $8 \mathrm{~h}$, and then analyzed by ESI-MS. A new signal was observed at $\mathrm{m} / \mathrm{z}$ 1475.2583, which was assigned to the octahedral cage $\left\{[2]\left(\mathrm{SbF}_{6}\right)(\mathrm{Cl}) \cdot 10 \mathrm{H}_{2} \mathrm{O}\right\}^{4+}$. These experiments indicated that the structural transformation from the tetrahedral cage [1] to the octahedral cage [2] has been triggered by the larger anion $\left(\mathrm{SbF}_{6}^{-}\right)$.

4.10. Preparation of $[\mathbf{1}]\left(\mathrm{BF}_{4}\right)_{4} / \mathrm{KBr}$ Thin Film. Transparent and uniform wafers suitable for third-order NLO tests were obtained by $\mathrm{KBr}$ pressed-disk technique. Firstly, [1] $\left(\mathrm{BF}_{4}\right)_{4}$ $(0.002 \mathrm{~g}, 0.0005 \mathrm{mmol})$ was ground into a fine powder in an agate mortar. Then, dry pure $\mathrm{KBr}$ (AR grade) $(0.500 \mathrm{~g}$ ) was added to the agate mortar and ground with the powder of $[1]\left(\mathrm{BF}_{4}\right)_{4}$, giving a particle size of ca. $2 \mu \mathrm{m}$ (200 mesh). Finally, ca. $0.025 \mathrm{~g}$ of the mixture was evenly spread in a clean mold. An automatic powder press of 8 tons was maintained for 20 to $30 \mathrm{~s}$ to give a transparent sheet that was used for the NLO test. The diameter and thickness of the transparent sheet were $13 \mathrm{~mm}$ and $0.12 \mathrm{~mm}$, respectively.

4.11. Preparation of $[\mathbf{1}]\left(\mathrm{ClO}_{4}\right)_{4} / \mathrm{KBr}$ Thin Film. The preparation method of $[\mathbf{1}]\left(\mathrm{ClO}_{4}\right)_{4} / \mathrm{KBr}$ thin film was similar to that used for the preparation of $[1]\left(\mathrm{BF}_{4}\right)_{4} / \mathrm{KBr}$ thin film. The $[1]\left(\mathrm{ClO}_{4}\right)_{4} / \mathrm{KBr}$ thin film was obtained by substituting $[1]\left(\mathrm{BF}_{4}\right)_{4}(0.002 \mathrm{~g}, 0.0005 \mathrm{mmol})$ for $[1]\left(\mathrm{ClO}_{4}\right)_{4}(0.002 \mathrm{~g}$, $0.0005 \mathrm{mmol})$. The diameter and thickness of the transparent sheet were $13 \mathrm{~mm}$ and $0.12 \mathrm{~mm}$, respectively.

4.12. Preparation of $[\mathbf{1}]\left(\mathrm{PF}_{6}\right)_{4} / \mathrm{KBr}$ Thin Film. The preparation method of $[\mathbf{1}]\left(\mathrm{PF}_{6}\right)_{4} / \mathrm{KBr}$ thin film was similar to that used for the preparation of $[1]\left(\mathrm{BF}_{4}\right)_{4} / \mathrm{KBr}$ thin film. The $[1]\left(\mathrm{PF}_{6}\right)_{4} / \mathrm{KBr}$ thin film was obtained by substituting $[\mathbf{1}]\left(\mathrm{BF}_{4}\right)_{4} \quad(0.002 \mathrm{~g}, 0.0005 \mathrm{mmol})$ for $[\mathbf{1}]\left(\mathrm{PF}_{6}\right)_{4} \quad(0.002 \mathrm{~g}$, $0.0005 \mathrm{mmol})$. The diameter and thickness of the transparent sheet were $13 \mathrm{~mm}$ and $0.12 \mathrm{~mm}$, respectively.

4.13. Preparation of $[2]\left(\mathrm{SbF}_{6}\right)_{6} / \mathrm{KBr}$ Thin Film. The preparation method of $[2]\left(\mathrm{SbF}_{6}\right)_{6} / \mathrm{KBr}$ thin film was similar to that used for the preparation of $[\mathbf{1}]\left(\mathrm{BF}_{4}\right)_{4} / \mathrm{KBr}$ thin film. The $[2]\left(\mathrm{SbF}_{6}\right)_{6} / \mathrm{KBr}$ thin film was obtained by substituting $[\mathbf{1}]\left(\mathrm{BF}_{4}\right)_{4}(0.002 \mathrm{~g}, 0.0005 \mathrm{mmol})$ for $[2]\left(\mathrm{SbF}_{6}\right)_{6}(0.003 \mathrm{~g}$, $0.0005 \mathrm{mmol})$. The diameter and thickness of the transparent sheet were $13 \mathrm{~mm}$ and $0.12 \mathrm{~mm}$, respectively.

4.14. Preparation of $\mathrm{A} / \mathrm{KBr}$ Thin Film. The preparation method of $\mathbf{A} / \mathrm{KBr}$ thin film was similar to that used for the preparation of $[\mathbf{1}]\left(\mathrm{BF}_{4}\right)_{4} / \mathrm{KBr}$ thin film. The $\mathrm{A} / \mathrm{KBr}$ thin film was obtained by substituting $[\mathbf{1}]\left(\mathrm{BF}_{4}\right)_{4} \quad(0.002 \mathrm{~g}$, $0.0005 \mathrm{mmol})$ for $\mathbf{A}(0.001 \mathrm{~g}, 0.0005 \mathrm{mmol})$. The diameter and thickness of the transparent sheet were $13 \mathrm{~mm}$ and $0.12 \mathrm{~mm}$, respectively.

4.15. Third-Order NLO Measurements. The nanosecond Z-scan technique and a linear polarized laser light $(\lambda=532 \mathrm{~nm}$; repetition rate $=10 \mathrm{~Hz}$; width $=4 \mathrm{~ns})$ generated from a frequency-doubled, mode-locked, Q-switched Nd: YAG laser were applied to measure their third-order NLO performance. All samples were mounted on a computercontrolled translation stage that shifted each sample along the $z$-axis, and all measurements were conducted at room temperature. The nonlinear absorption data for all samples were collected using the Z-scan technique with openaperture settings. For the KBr-based cage thin films, the incident pulse energy of $21 \mu \mathrm{j}$ was employed. For the solution 
samples, the higher incident pulse energy of $28 \mu \mathrm{j}$ was employed. A valley at the zero point indicated the reverse saturable absorption (RSA) response, and the depth of the valley symbolizes the strength of RSA signal. All experimental data were numerically fitted according to Bahae et al.'s theory, and the obtained effective nonlinear absorption coefficient $\beta$ value are listed in Table S2.

\section{Data Availability}

All data that support the findings of this study are available from the corresponding author upon reasonable request.

\section{Conflicts of Interest}

The authors declare that there is no conflict of interest regarding the publication of this article.

\section{Authors' Contributions}

S. J. Bao, Z. Niu, and J. P. Lang conceived and designed the experiments, discussed the results, and wrote the manuscript. S. J. Bao performed experiments, determined structures, analyzed data, and wrote the paper. Z. M. $\mathrm{Xu}$ assisted in the structural characterization of the title compounds and analyzed data. T. C. Yu and Y. L. Song performed Z-scan experiments for third-order NLO properties. H. Wang and X. B. Li performed ESI-MS experiments and provided isotopic distribution patterns of all compounds. B. F. Abrahams and P. Braunstein discussed and revised the manuscript. J. P. Lang and Z. Niu directed the research. All authors contributed to the analysis of the results and edited the manuscript.

\section{Acknowledgments}

This work was supported by the National Natural Science Foundation of China (grant numbers 21531006 and 21773163); the State Key Laboratory of Organometallic Chemistry of Shanghai Institute of Organic Chemistry (grant number KF2021005); Collaborative Innovation Center of Suzhou Nano Science and Technology; the Project of Scientific and Technologic Infrastructure of Suzhou (grant number SZS201905); and Postgraduate Research \& Practice Innovation Program of Jiangsu Province (grant number: KYCX21_2938).

\section{Supplementary Materials}

Fig. S1: experimental (top) and theoretical (bottom) ESITOF-MS spectra of $\left\{[\mathbf{1}]\left(\mathrm{BF}_{4}\right)\right\}^{3+}$ in $[\mathbf{1}]\left(\mathrm{BF}_{4}\right)_{4}$. Fig. S2: experimental (top) and theoretical (bottom) ESI-TOF-MS spectra of $\left\{[\mathbf{1}]\left(\mathrm{ClO}_{4}\right)\right\}^{3+}$ in $[\mathbf{1}]\left(\mathrm{ClO}_{4}\right)_{4}$. Fig. S3: experimental (top) and theoretical (bottom) ESI-TOF-MS spectra of $\left\{[\mathbf{1}]\left(\mathrm{PF}_{6}\right)\right\}^{3+}$ in $[\mathbf{1}]\left(\mathrm{PF}_{6}\right)_{4}$. Fig. S4: experimental (top) and theoretical (bottom) ESI-TOF-MS spectra of $\left\{[1]\left(\mathrm{PF}_{6}\right) 2\right\}^{2+}$ in $[1]\left(\mathrm{PF}_{6}\right)_{4}$. Fig. S5: experimental (top) and theoretical (bottom) ESI-TOF-MS spectra of $\left\{[2]\left(\mathrm{SbF}_{6}\right)(\mathrm{Cl}) \cdot 10 \mathrm{H}_{2} \mathrm{O}\right\}^{4+}$ in $[2]\left(\mathrm{SbF}_{6}\right)_{6}$. Fig. S6: ${ }^{1} \mathrm{H}$ NMR spectrum of ligand $\mathbf{L}$ $\left(400 \mathrm{MHz}, 298 \mathrm{~K}, \mathrm{CDCl}_{3}, \mathrm{ppm}\right)$. Fig. S7: ${ }^{13} \mathrm{C} \mathrm{NMR}$ spec- trum of ligand $\mathbf{L}\left(101 \mathrm{MHz}, 298 \mathrm{~K}, \mathrm{CDCl}_{3}\right.$, ppm). Fig. S8: ${ }^{1} \mathrm{H}$ NMR spectrum of $[1]\left(\mathrm{BF}_{4}\right)_{4}\left(600 \mathrm{MHz}, 298 \mathrm{~K}, \mathrm{CD}_{3} \mathrm{CN}\right.$, ppm). Fig. S9: ${ }^{1} \mathrm{H}-{ }^{1} \mathrm{H}$ COSY NMR spectrum of $[1]\left(\mathrm{BF}_{4}\right)_{4}$ $\left(600 \mathrm{MHz}, 298 \mathrm{~K}, \mathrm{CD}_{3} \mathrm{CN}, \mathrm{ppm}\right)$. Fig. S10: ${ }^{1} \mathrm{H}$ DOSY NMR spectrum of $[\mathbf{1}]\left(\mathrm{BF}_{4}\right)_{4}\left(600 \mathrm{MHz}, 298 \mathrm{~K}, \mathrm{CD}_{3} \mathrm{CN}\right.$, ppm). Fig. S11: ${ }^{1} \mathrm{H}$ NMR spectrum of $[\mathbf{1}]\left(\mathrm{ClO}_{4}\right)_{4}$ $\left(600 \mathrm{MHz}, 298 \mathrm{~K}, \mathrm{CD}_{3} \mathrm{CN}, \mathrm{ppm}\right)$. Fig. S12: ${ }^{1} \mathrm{H}-{ }^{1} \mathrm{H}$ COSY NMR spectrum of $[\mathbf{1}]\left(\mathrm{ClO}_{4}\right)_{4}\left(600 \mathrm{MHz}, 298 \mathrm{~K}, \mathrm{CD}_{3} \mathrm{CN}\right.$, ppm). Fig. S13: ${ }^{1} \mathrm{H}$ DOSY NMR spectrum of $[\mathbf{1}]\left(\mathrm{ClO}_{4}\right)_{4}$ $\left(600 \mathrm{MHz}, 298 \mathrm{~K}, \mathrm{CD}_{3} \mathrm{CN}, \mathrm{ppm}\right)$. Fig. S14: ${ }^{1} \mathrm{H}$ NMR spectrum of $[1]\left(\mathrm{PF}_{6}\right)_{4}\left(600 \mathrm{MHz}, 298 \mathrm{~K}, \mathrm{CD}_{3} \mathrm{CN}, \mathrm{ppm}\right)$. Fig. S15: ${ }^{1} \mathrm{H}-{ }^{1} \mathrm{H}$ COSY NMR spectrum of $[\mathbf{1}]\left(\mathrm{PF}_{6}\right)_{4}$ $\left(600 \mathrm{MHz}, 298 \mathrm{~K}, \mathrm{CD}_{3} \mathrm{CN}, \mathrm{ppm}\right)$. Fig. S16: ${ }^{1} \mathrm{H}$ DOSY NMR spectrum of $[1]\left(\mathrm{PF}_{6}\right)_{4}\left(600 \mathrm{MHz}, 298 \mathrm{~K}, \mathrm{CD}_{3} \mathrm{CN}\right.$, ppm). Fig. S17: ${ }^{1} \mathrm{H}$ NMR spectrum of $[2]\left(\mathrm{SbF}_{6}\right)_{6}$ $\left(600 \mathrm{MHz}, 298 \mathrm{~K}, \mathrm{CD}_{3} \mathrm{CN}, \mathrm{ppm}\right)$. Fig. S18: ${ }^{1} \mathrm{H}-{ }^{1} \mathrm{H}$ COSY NMR spectrum of $[2]\left(\mathrm{SbF}_{6}\right)_{6}\left(600 \mathrm{MHz}, 298 \mathrm{~K}, \mathrm{CD}_{3} \mathrm{CN}\right.$, ppm). Fig. S19: ${ }^{1} \mathrm{H}$ DOSY NMR spectrum of $[2]\left(\mathrm{SbF}_{6}\right)_{6}$ $\left(600 \mathrm{MHz}, 298 \mathrm{~K}, \mathrm{CD}_{3} \mathrm{CN}\right.$, ppm). Fig. S20: a representation of single vertex (the $\left[T p^{*} \mathrm{WS}_{3} \mathrm{Cu}_{2}\left(\mathrm{~L}^{\mathbf{a}}\right)\right]^{+}$unit) consisting of the $\mathrm{C}_{3}$-symmetry $\mathrm{Tp}^{*} \mathrm{WS}_{3}$ moiety, two $\mathrm{Cu}(\mathrm{I})$ ions and one linker La in tetrahedral cage [1]. Fig. S21: view of the structure of the tetrahedral cage $[\mathbf{1}]\left(\mathrm{BF}_{4}\right)_{4}$ showing the inclusion of one $\mathrm{BF}_{4}^{-}$with a space filling representation within the cavity as well as three external $\mathrm{BF}_{4}^{-}$anions. Fig. S22: one pair of enantiomers of the tetrahedral cage of [1]. Fig. S23: one pair of enantiomers packing in one unit cell of $[\mathbf{1}]\left(\mathrm{BF}_{4}\right)_{4}$, forming a racemic crystal. Fig. S24: the host-guest interactions between the internal $\mathrm{BF}_{4}{ }^{-}$and the tetrahedral host $[\mathbf{1}]$ in $[\mathbf{1}]\left(\mathrm{BF}_{4}\right)_{4}$. (A) The hydrogen bonding interactions. (B) The F $\cdots \pi$ interactions. Fig. S25: single-crystal X-ray structure of the tetrahedral cages $[\mathbf{1}]\left(\mathrm{ClO}_{4}\right)_{4}$ and $[\mathbf{1}]\left(\mathrm{PF}_{6}\right)_{4}$. Fig. S26: the topology of three isostructural tetrahedral assemblies $[\mathbf{1}]\left(\mathrm{BF}_{4}\right)_{4}$, $[\mathbf{1}]\left(\mathrm{ClO}_{4}\right)_{4}$, and $[\mathbf{1}]\left(\mathrm{PF}_{6}\right)_{4}$, showing the angles of $\alpha$ in vertex being $42.51^{\circ}, 42.26^{\circ}$, and $43.60^{\circ}$, respectively. Fig. S27: the host-guest interactions between the internal $\mathrm{ClO}_{4}^{-}$ and the tetrahedral host $[\mathbf{1}]$ in $[\mathbf{1}]\left(\mathrm{ClO}_{4}\right)_{4}$. (A) The hydrogen bonding interactions. (B) The $\mathrm{O} \cdots \pi$ interactions. Fig. S28: the host-guest interactions between the internal $\mathrm{PF}_{6}{ }^{-}$and the tetrahedral host $[\mathbf{1}]$ in $[\mathbf{1}]\left(\mathrm{PF}_{6}\right)_{4}$. (A) The hydrogen bonding interactions. (B) The F $\cdots \pi$ interactions. Fig. S29: view of the asymmetric unit of $[2]\left(\mathrm{SbF}_{6}\right)_{6}$. Fig. S30: single-crystal X-ray structure of octahedral cage [2]. Fig. S31: the TGA curves of $[\mathbf{1}]\left(\mathrm{BF}_{4}\right)_{4},[\mathbf{1}]\left(\mathrm{ClO}_{4}\right)_{4}$, $[1]\left(\mathrm{PF}_{6}\right)_{4}$, and $[2]\left(\mathrm{SbF}_{6}\right)_{6}$ in a $\mathrm{N}_{2}$ atmosphere from room temperature to $800^{\circ} \mathrm{C}$. Fig. S32: view of the structure of the octahedral cage $[2]\left(\mathrm{SbF}_{6}\right)_{6}$ showing the inclusion of two $\mathrm{SbF}_{6}^{-}$anions with a space filling representation within the cavity as well as four external $\mathrm{SbF}_{6}{ }^{-}$anions. Fig. S33: the host-guest interactions between the internal $\mathrm{SbF}_{6}{ }^{-}$and the octahedral host [2] in $[2]\left(\mathrm{SbF}_{6}\right)_{6}$. (A) The hydrogen bonding interactions. (B) The F... $\pi$ interactions. Fig. S34: the ESI-MS spectrum after addition of excess $\left(\mathrm{Et}_{4} \mathrm{~N}\right)\left(\mathrm{SbF}_{6}\right)$ to the MeCN solution of the tetrahedral compound $[\mathbf{1}]\left(\mathrm{BF}_{4}\right)_{4}$, showing no any octahedral cage signal. Fig. S35: normalized UV-Vis absorption spectra of A $\left(8.71 \times 10^{-5} \mathrm{M}\right), \quad[1]\left(\mathrm{BF}_{4}\right)_{4} \quad\left(1.53 \times 10^{-5} \mathrm{M}\right)$, $[\mathbf{1}]\left(\mathrm{ClO}_{4}\right)_{4}\left(1.73 \times 10^{-5} \mathrm{M}\right),[\mathbf{1}]\left(\mathrm{PF}_{6}\right)_{4}\left(1.73 \times 10^{-5} \mathrm{M}\right)$, and 
[2] $\left(\mathrm{SbF}_{6}\right)_{6}\left(1.38 \times 10^{-5} \mathrm{M}\right)$ in DMF in a $1 \mathrm{~cm}$ thick glass cell. Fig. S36: normalized solid UV-Vis absorption spectra of the $\mathrm{KBr}$-based thin films of $\mathbf{A},[\mathbf{1}]\left(\mathrm{BF}_{4}\right)_{4},[\mathbf{1}]\left(\mathrm{ClO}_{4}\right)_{4}$, $[1]\left(\mathrm{PF}_{6}\right)_{4}$, and $[2]\left(\mathrm{SbF}_{6}\right)_{6}$ and the pure $\mathrm{KBr}$ thin film. Fig. S37: normalized Z-scan data of pure DMF under open-aperture conditions, displaying no detectable signal for absorption performance. Fig. S38: normalized Z-scan data of the pure $\mathrm{KBr}$ thin film under open-aperture conditions, displaying no detectable signal for absorption performance. Fig. S39: normalized Z-scan data of $\mathbf{A}$ in DMF $\left(1.38 \times 10^{-4} \mathrm{~mol} / \mathrm{L}\right)$ under open-aperture conditions, displaying no detectable signal for absorption performance. Fig. S40: normalized Z-scan data of the $\mathrm{A} / \mathrm{KBr}$ thin film under open-aperture conditions, displaying no detectable signal for absorption performance. Fig. S41: normalized Z-scan data of the $\mathrm{KBr}$-based thin film of $[1]\left(\mathrm{ClO}_{4}\right)_{4}$ and its DMF solution under open-aperture conditions, displaying a reversed saturable absorption response. Fig. S42: normalized Z-scan data of the KBr-based thin film of $[1]\left(\mathrm{PF}_{6}\right)_{4}$ and its DMF solution under open-aperture conditions, displaying a reversed saturable absorption response. Fig. S43: normalized Z-scan data of DMF solutions of $[1]\left(\mathrm{BF}_{4}\right)_{4}$ at concentrations $2.07 \times 10^{-4} \mathrm{~mol} / \mathrm{L}$ and $2.76 \times 10^{-4} \mathrm{~mol} / \mathrm{L}$ under open-aperture conditions. Fig. S44: normalized Z-scan data of DMF solutions of $[2]\left(\mathrm{SbF}_{6}\right)_{6}$ at concentrations $2.07 \times 10^{-4} \mathrm{~mol} / \mathrm{L}$ and 2.76 $\times 10^{-4} \mathrm{~mol} / \mathrm{L}$ under open-aperture conditions. Table S1: summary of crystal data and structure refinement parameters for $[\mathbf{1}]\left(\mathrm{BF}_{4}\right)_{4},[\mathbf{1}]\left(\mathrm{ClO}_{4}\right)_{4},[\mathbf{1}]\left(\mathrm{PF}_{6}\right)_{4}$, and $[2]\left(\mathrm{SbF}_{6}\right)_{6}$. Table S2: the third-order NLO parameters for $[\mathbf{1}]\left(\mathrm{BF}_{4}\right)_{4}$ in DMF, $[\mathbf{1}]\left(\mathrm{ClO}_{4}\right)_{4}$ in DMF, $[\mathbf{1}]\left(\mathrm{PF}_{6}\right)_{4}$ in DMF, [2] $\left(\mathrm{SbF}_{6}\right)_{6}$ in DMF, $[\mathbf{1}]\left(\mathrm{BF}_{4}\right)_{4} / \mathrm{KBr}$ thin film, $[\mathbf{1}]\left(\mathrm{ClO}_{4}\right)_{4} /$ $\mathrm{KBr}$ thin film, $[\mathbf{1}]\left(\mathrm{PF}_{6}\right)_{4} / \mathrm{KBr}$ thin film, and $[2]\left(\mathrm{SbF}_{6}\right)_{6} /$ $\mathrm{KBr}$ thin film. (Supplementary Materials)

\section{References}

[1] T. R. Cook and P. J. Stang, "Recent developments in the preparation and chemistry of metallacycles and metallacages via coordination," Chemical Reviews, vol. 115, no. 15, pp. 7001$7045,2015$.

[2] Q. F. Sun, J. Iwasa, D. Ogawa et al., "Self-assembled $\mathrm{M}_{24} \mathrm{~L}_{48}$ polyhedra and their sharp structural switch upon subtle ligand variation," Science, vol. 328, no. 5982, pp. 11441147, 2010.

[3] E. G. Percástegui, T. K. Ronson, and J. R. Nitschke, "Design and applications of water-soluble coordination cages," Chemical Reviews, vol. 120, no. 24, pp. 13480-13544, 2020.

[4] M. Han, D. M. Engelhard, and G. H. Clever, "Self-assembled coordination cages based on banana-shaped ligands," Chemical Society Reviews, vol. 43, no. 6, pp. 1848-1860, 2014.

[5] W. Wang, Y. X. Wang, and H. B. Yang, "Supramolecular transformations within discrete coordination-driven supramolecular architectures," Chemical Society Reviews, vol. 45, no. 9, pp. 2656-2693, 2016.

[6] Y. Y. Zhang, W. X. Gao, L. Lin, and G. X. Jin, "Recent advances in the construction and applications of heterometallic macrocycles and cages," Coordination Chemistry Reviews, vol. 344, pp. 323-344, 2017.
[7] H. Sepehrpour, W. Fu, Y. Sun, and P. J. Stang, "Biomedically relevant self-assembled metallacycles and metallacages," Journal of the American Chemical Society, vol. 141, no. 36, pp. 14005-14020, 2019.

[8] T. R. Cook, V. Vajpayee, M. H. Lee, P. J. Stang, and K. W. Chi, "Biomedical and biochemical applications of self-assembled metallacycles and metallacages," Accounts of Chemical Research, vol. 46, no. 11, pp. 2464-2474, 2013.

[9] N. Ahmad, H. A. Younus, A. H. Chughtai, and F. Verpoort, "Metal-organic molecular cages: applications of biochemical implications," Chemical Society Reviews, vol. 44, no. 1, pp. 925, 2015.

[10] M. Yoshizawa, M. Tamura, and M. Fujita, "Diels-Alder in aqueous molecular hosts: unusual regioselectivity and efficient catalysis," Science, vol. 312, no. 5771, pp. 251-254, 2006.

[11] C. M. Hong, R. G. Bergman, K. N. Raymond, and F. D. Toste, "Self-assembled tetrahedral hosts as supramolecular catalysts," Accounts of Chemical Research, vol. 51, no. 10, pp. 2447-2455, 2018.

[12] D. M. Kaphan, M. D. Levin, R. G. Bergman, K. N. Raymond, and F. D. Toste, "A supramolecular microenvironment strategy for transition metal catalysis," Science, vol. 350, no. 6265, pp. 1235-1238, 2015.

[13] J. Jiao, C. Tan, Z. Li, Y. Liu, X. Han, and Y. Cui, "Design and assembly of chiral coordination cages for asymmetric sequential reactions," Journal of the American Chemical Society, vol. 140, no. 6, pp. 2251-2259, 2018.

[14] J. S. Wang, K. Wu, C. Yin et al., "Cage-confined photocatalysis for wide-scope unusually selective $[2+2]$ cycloaddition through visible-light triplet sensitization," Nature Communications, vol. 11, no. 1, p. 4675, 2020.

[15] J. L. Zhu, D. Zhang, T. K. Ronson et al., "A cavity-tailored metal-organic cage entraps gases selectively in solution and the amorphous solid state," Angewandte Chemie International Edition, vol. 60, no. 21, pp. 11789-11792, 2021.

[16] X. Zhang, X. Dong, W. Lu et al., "Fine-tuning apertures of metal-organic cages: encapsulation of carbon dioxide in solution and solid state," Journal of the American Chemical Society, vol. 141, no. 29, pp. 11621-11627, 2019.

[17] L. J. Wang, X. Li, S. Bai, Y. Y. Wang, and Y. F. Han, "Selfassembly, structural transformation, and guest-binding properties of supramolecular assemblies with triangular metal-metal bonded units," Journal of the American Chemical Society, vol. 142, no. 5, pp. 2524-2531, 2020.

[18] D. Zhang, T. K. Ronson, Y. Q. Zou, and J. R. Nitschke, "Metalorganic cages for molecular separations," Nature Reviews Chemistry, vol. 5, no. 3, pp. 168-182, 2021.

[19] Y. Shi, K. Cai, H. Xiao et al., "Selective extraction of $C_{70}$ by a tetragonal prismatic porphyrin cage," Journal of the American Chemical Society, vol. 140, no. 42, pp. 13835-13842, 2018.

[20] X. Yan, T. R. Cook, P. Wang, F. Huang, and P. J. Stang, "Highly emissive platinum(II) metallacages," Nature Chemistry, vol. 7, no. 4, pp. 342-348, 2015.

[21] K. Ono, J. K. Klosterman, M. Yoshizawa, K. Sekiguchi, T. Tahara, and M. Fujita, "ON/OFF red emission from azaporphine in a coordination cage in water," Journal of the American Chemical Society, vol. 131, no. 35, pp. 12526-12527, 2009.

[22] C. Mu, Z. Zhang, Y. Hou et al., "Tetraphenylethylene-based multicomponent emissive metallacages as solid-state fluorescent materials," Angewandte Chemie International Edition, vol. 60, no. 22, pp. 12293-12297, 2021. 
[23] X. Tang, D. Chu, W. Gong, Y. Cui, and Y. Liu, "Metal-organic cages with missing linker defects," Angewandte Chemie International Edition, vol. 60, no. 16, pp. 9099-9105, 2021.

[24] J. Tessarolo, H. Lee, E. Sakuda, K. Umakoshi, and G. H. Clever, "Integrative assembly of heteroleptic tetrahedra controlled by backbone steric bulk," Journal of the American Chemical Society, vol. 143, no. 17, pp. 6339-6344, 2021.

[25] H. Wang, L. P. Zhou, Y. Zheng et al., "Double-layered supramolecular prisms self-assembled by geometrically nonequivalent tetratopic subunits," Angewandte Chemie International Edition, vol. 60, no. 3, pp. 1298-1305, 2021.

[26] S. Saha, I. Regeni, and G. H. Clever, "Structure relationships between bis-monodentate ligands and coordination driven self-assemblies," Coordination Chemistry Reviews, vol. 374, pp. 1-14, 2018.

[27] P. J. Stang and B. Olenyuk, "Self-assembly, symmetry, and molecular architecture: coordination as the motif in the rational design of supramolecular metallacyclic polygons and polyhedra," Accounts of Chemical Research, vol. 30, no. 12, pp. 502-518, 1997.

[28] R. Chakrabarty, P. S. Mukherjee, and P. J. Stang, "Supramolecular coordination: self-assembly of finite two- and threedimensional ensembles," Chemical Reviews, vol. 111, no. 11, pp. 6810-6918, 2011.

[29] N. J. Young and B. P. Hay, "Structural design principles for self-assembled coordination polygons and polyhedra," Chemical Communications, vol. 49, no. 14, pp. 1354-1379, 2013.

[30] D. J. Tranchemontagne, Z. Ni, M. O'Keeffe, and O. M. Yaghi, "Reticular chemistry of metal-organic polyhedra," Angewandte Chemie International Edition, vol. 47, no. 28, pp. 5136-5147, 2008.

[31] J. P. Carpenter, C. T. McTernan, T. K. Ronson, and J. R. Nitschke, "Anion pairs template a trigonal prism with disilver vertices," Journal of the American Chemical Society, vol. 141, no. 29, pp. 11409-11413, 2019.

[32] Z. K. Zhu, Y. Y. Lin, H. Yu, X. X. Li, and S. T. Zheng, "Inorganic-organic hybrid polyoxoniobates: polyoxoniobate metal complex cage and cage framework," Angewandte Chemie International Edition, vol. 58, no. 47, pp. 16864-16868, 2019.

[33] G. Liu, Y. di Yuan, J. Wang et al., "Process-tracing study on the postassembly modification of highly stable zirconium metalorganic cages," Journal of the American Chemical Society, vol. 140, no. 20, pp. 6231-6234, 2018.

[34] N. Xu, H. Gan, C. Qin, X. Wang, and Z. Su, "From octahedral to icosahedral metal-organic polyhedra assembled from two types of polyoxovanadate clusters," Angewandte Chemie International Edition, vol. 58, no. 14, pp. 4649-4653, 2019.

[35] Y. Zhang, H. Gan, C. Qin, X. Wang, Z. Su, and M. J. Zaworotko, "Self-assembly of Goldberg polyhedra from a concave $\left[\mathrm{WV}_{5} \mathrm{O}_{11}\left(\mathrm{RCO}_{2}\right)_{5}\left(\mathrm{SO}_{4}\right)\right]^{3-}$ building block with 5 -fold symmetry," Journal of the American Chemical Society, vol. 140, no. 50, pp. 17365-17368, 2018.

[36] S. J. Bao, Z. M. Xu, Y. Ju et al., "The covalent and coordination co-driven assembly of supramolecular octahedral cages with controllable degree of distortion," Journal of the American Chemical Society, vol. 142, no. 31, pp. 13356-13361, 2020.

[37] S. Wang, T. Sawada, K. Ohara, K. Yamaguchi, and M. Fujita, "Capsule-capsule conversion by guest encapsulation," Angewandte Chemie International Edition, vol. 55, no. 6, pp. 2063-2066, 2016.
[38] D. Zhang, T. K. Ronson, J. Mosquera, A. Martinez, L. Guy, and J. R. Nitschke, "Anion binding in water drives structural adaptation in an azaphosphatrane-functionalized $\mathrm{Fe}^{\mathrm{II}}{ }_{4} \mathrm{~L}_{4}$ tetrahedron," Journal of the American Chemical Society, vol. 139, no. 19, pp. 6574-6577, 2017.

[39] E. G. Percástegui, "Guest-induced transformations in metalorganic cages," European Journal of Inorganic Chemistry, vol. 2021, no. 43, pp. 4425-4438, 2021.

[40] H. Hou, K. Zhou, F. Jiang, Q. Chen, and M. Hong, "Controllable coordination self-assembly based on flexibility of ligands: synthesis of supramolecular assemblies and stimuli-driven structural transformations," Israel Journal of Chemistry, vol. 59, no. 3-4, pp. 140-150, 2019.

[41] I. A. Riddell, Y. R. Hristova, J. K. Clegg, C. S. Wood, B. Breiner, and J. R. Nitschke, "Five discrete multinuclear metal-organic assemblies from one ligand: deciphering the effects of different templates," Journal of the American Chemical Society, vol. 135, no. 7, pp. 2723-2733, 2013.

[42] R. Custelcean, P. V. Bonnesen, N. C. Duncan et al., "Ureafunctionalized $\mathrm{M}_{4} \mathrm{~L}_{6}$ cage receptors: anion-templated selfassembly and selective guest exchange in aqueous solutions," Journal of the American Chemical Society, vol. 134, no. 20, pp. 8525-8534, 2012.

[43] C. S. Campos-Fernández, B. L. Schottel, H. T. Chifotides et al., "Anion template effect on the self-assembly and interconversion of metallacyclophanes," Journal of the American Chemical Society, vol. 127, no. 37, pp. 12909-12923, 2005.

[44] I. A. Riddell, M. M. J. Smulders, J. K. Clegg et al., "Anioninduced reconstitution of a self-assembling system to express a chloride-binding $\mathrm{Co}_{10} \mathrm{~L}_{15}$ pentagonal prism," Nature Chemistry, vol. 4, no. 9, pp. 751-756, 2012.

[45] I. A. Riddell, T. K. Ronson, J. K. Clegg, C. S. Wood, R. A. Bilbeisi, and J. R. Nitschke, "Cation- and anion-exchanges induce multiple distinct rearrangements within metallosupramolecular architectures," Journal of the American Chemical Society, vol. 136, no. 26, pp. 9491-9498, 2014.

[46] H. Kawaguchi and $\mathrm{K}$. Tatsumi, "Facile route to the trithiotungsten(VI) complex $\left(\mathrm{PPh}_{4}\right)\left[\left(\mathrm{C}_{5} \mathrm{Me}_{5}\right) \mathrm{W}(\mathrm{S})_{3}\right]$ via carbon-sulfur bond cleavage of ethanedithiolate and its reactions with alkyl halides and alkynes," Journal of the American Chemical Society, vol. 117, no. 13, pp. 3885-3886, 1995.

[47] R. M. McKinlay, P. K. Thallapally, G. W. V. Cave, and J. L. Atwood, "Hydrogen-bonded supramolecular assemblies as robust templates in the synthesis of large metal-coordinated capsules," Angewandte Chemie International Edition, vol. 44, no. 35, pp. 5733-5736, 2005.

[48] H. T. Chifotides and K. R. Dunbar, "Anion- $\pi$ interactions in supramolecular architectures," Accounts of Chemical Research, vol. 46, no. 4, pp. 894-906, 2013.

[49] H. Zeng, P. Liu, G. Feng, and F. Huang, " $\pi$-Metalated $\left[1_{5}\right]$ paracyclophanes: synthesis and binding to oxo-anions via anion $-\pi$ interactions," Journal of the American Chemical Society, vol. 141, no. 41, pp. 16501-16511, 2019.

[50] Y. P. He, G. H. Chen, D. J. Li, Q. H. Li, L. Zhang, and J. Zhang, "Combining a titanium-organic cage and a hydrogen-bonded organic cage for highly effective third-order nonlinear optics," Angewandte Chemie International Edition, vol. 60, no. 6, pp. 2920-2923, 2021.

[51] J. Jia, X. Zhang, Y. Wang et al., "Enhanced two-photon absorption of cross-conjugated chalcone derivatives: modulation of the effective $\pi$-conjugated structure," The Journal of Physical Chemistry A, vol. 124, no. 51, pp. 10808-10816, 2020. 
[52] M. Sheik-Bahae, A. A. Said, T. H. Wei, D. J. Hagan, and E. W. van Stryland, "Sensitive measurement of optical nonlinearities using a single beam," IEEE Journal of Quantum Electronics, vol. 26, no. 4, pp. 760-769, 1990.

[53] H. Fan, X. Wang, Q. Ren et al., "Third-order nonlinear optical properties in $\left[\left(\mathrm{C}_{4} \mathrm{H}_{9}\right)_{4} \mathrm{~N}\right]_{2}\left[\mathrm{Cu}\left(\mathrm{C}_{3} \mathrm{~S}_{5}\right)_{2}\right]$-doped PMMA thin film using Z-scan technique in picosecond pulse," Applied Physics $A$, vol. 99, no. 1, pp. 279-284, 2010.

[54] H. Seino, Y. Arai, N. Iwata, S. Nagao, Y. Mizobe, and M. Hidai, "Preparation of mononuclear tungsten tris (sulfido) and molybdenum sulfido-tetrasulfido complexes with hydridotris (pyrazolyl) borate coligand and conversion of the former into sulfido-bridged bimetallic complex having Pt $(\mu-S)_{2}$ WS core," Inorganic Chemistry, vol. 40, no. 7, pp. 1677-1682, 2001.

[55] M. Albrecht, M. Nieger, and A. Schmidt, "A metal-organic framework constructed of 1, 4-di(pyridin-4-yl)-buta-1, 3diyne and nickel (II) nitrate," Zeitschrift für Naturforschung Part B, vol. 66, no. 2, pp. 209-212, 2011. 